\title{
New triterpene and triterpenoid glycosides from Ilex brevicuspis
}

\author{
Alexandre T. Cardoso Taketa', Manfred Gondorf', Eberhard Breitmaier', Eloir Paulo Schenkel2* \\ ${ }^{1}$ Kekulé-Institut für Organische Chemie und Biochemie der Universität Bonn - Germany, ${ }^{2}$ Departamento de Ciências \\ Farmacêuticas, Centro de Ciências da Saúde,Universidade Federal de Santa Catarina
}

*Correspondence:

E.P. Schenkel

Departamento de Ciências

Farmacêuticas - Centro de Ciências da

Saúde

Universidade Federal de Santa

Catarina -Campus Universitário /

Trindade

88.040-900 - Florianópolis-SC, Brasil

E-mail: schenkel@ccs.ufsc.br
From the leaves of Ilex brevicuspis were isolated a new triterpene, 20 (S)-3 $\beta, 19 \alpha$-dihydroxyurs-12-en-23,28-dioic acid, named here brevicuspic acid, and two new triterpenoid glycosides, 3-O- $\alpha-L-$ arabinopyranosyl-20(S)-pomolic acid-28-O- $\beta$-D-glucopyranosyl ester, named brevicuspisaponin 3 , and the 23-sodium salt of (20S)$3 \beta, 19 \alpha, 24-t r i h y d r o x y u r s-12-e n-23,28$-dioic acid-28 $\beta$-O- $\beta$ - $D$ glucopyranosyl ester, along with the known compound 3-O- $\alpha-L-$ arabinopyranosyl-20(S)-19 $\alpha, 24$-dihydroxyursolic acid- 28-O- $\beta$ - Dglucopyranosyl ester, already described for Ilex argentina. Their structures were established on the basis of chemical and spectroscopic methods.

\section{Uniterms:}

- Aquifoliaceae

- Ilex brevicuspis

- Triterpenes

- Saponins

- Brevicuspic acid

- Brevicuspisaponins 3 and 4

\section{INTRODUCTION}

As previously reported, the leaves of Ilex brevicuspis Reissek (Aquifoliaceae) afforded the triterpenes ursolic acid, 23-methylester of 20(S)rotundioic acid, and the new glycosides brevicuspisaponin 1 and 2(Taketa et al., 2000). Continuing the investigation on the leaves of I. brevicuspis, as a part of our studies on the adulterants of the genuine maté, Ilex paraguariensis (Taketa, Schenkel.,1994; Schenkel et al.,1995; Heinzmann, Schenkel,1995; Pires et al., 1997; Schenkel et al.,1997; Athayde et al., 1999; Reginatto et al.,1999; Athayde et al., 2001), we report here further new triterpene and saponins from the title plant.

\section{MATERIAL AND METHODS}

\section{Plant material}

Leaves of Ilex brevicuspis Reissek were collected in Osório, State of Rio Grande do Sul, Brazil. A herbarium specimen (leg. Coelho 163) is on deposit in the Herbarium of the Botany Department of the Federal University of Rio
Grande do Sul (Herbarium ICN, Porto Alegre, Brazil).

\section{General experimental procedures}

Melting points were obtained in a Kofler melting point apparatus and are uncorrected. IR spectra were recorded in a Perkin-Elmer 881 spectrophotometer. Optical rotations were measured in a Perkin-Elmer 241 polarimeter. EIMS and HRMS spectra were performed in a MS50 spectrometer and FAB-MS spectra on a Concept $1 \mathrm{H}$ spectrometer. ${ }^{1} \mathrm{H}$ and ${ }^{13} \mathrm{C}$ NMR spectra were recorded in Bruker AMX and DRX 500 spectrometers. TLC were carried out on silica gel (Merck) $\mathrm{GF}_{254}$ and sugars and glycosides were eluted with EtOAc/ $\mathrm{MeOH} / \mathrm{HOAc} / \mathrm{H}_{2} \mathrm{O}$ $13: 3: 4: 3$. All compounds were visualized using the vanillin-sulfuric acid reagent $/ 100{ }^{\circ} \mathrm{C} / 10 \mathrm{~min}$. Open $\mathrm{CC}$ were performed on a normal phase silica gel 40-60 mm using the eluants $\mathrm{CHCl}_{3} / \mathrm{MeOH}$ 97:3 and cyclohexane/ acetone $1: 1$ to $\mathbf{1 a}$ and $\mathbf{2 a}, \mathrm{CHCl}_{3} / \mathrm{MeOH} 9: 1$ to $\mathbf{1}$ and $\mathrm{CHCl}_{3} / \mathrm{EtOH} / \mathrm{H}_{2} \mathrm{O} 8: 4: 0.5$ to 2, 3 and 4. For 3, the phase LiChroprep C-18, 40-63 mm, the eluant $\mathrm{MeOH} / \mathrm{H}_{2} \mathrm{O} 3: 1$ and Sephadex LH-20 in $\mathrm{MeOH}$ were used for final purifications. 


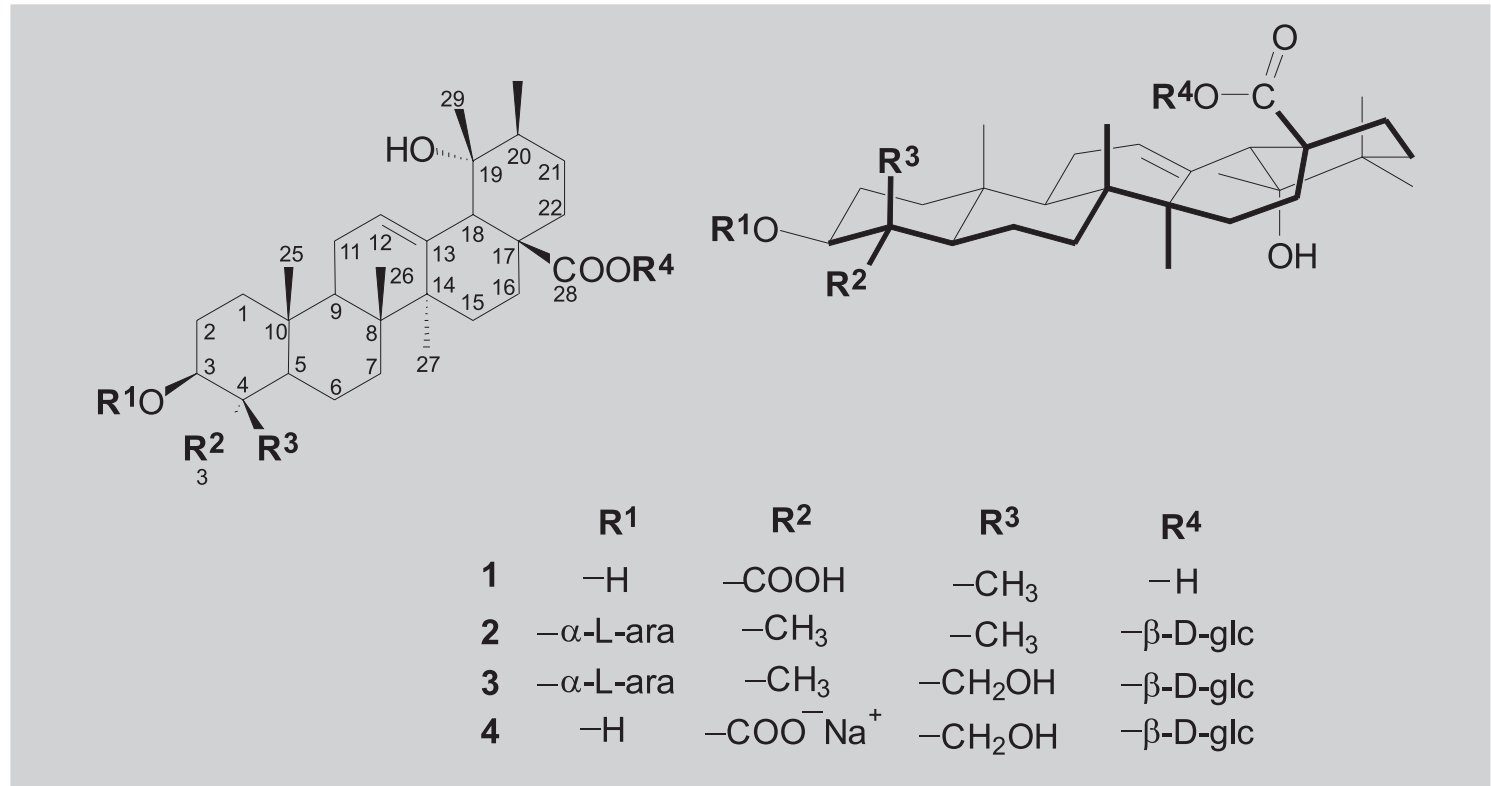

\section{Extraction and isolation}

Air-dried leaves $(589 \mathrm{~g})$ were crushed and extracted with ethanol $(1.5 \mathrm{~L})$ at room temperature $(2 \times 7$ days $)$. The ethanolic extract $(2 \mathrm{~L})$ was evaporated to dryness under reduced pressure and the residue ( $69 \mathrm{~g})$ was then suspended in water $(700 \mathrm{~mL})$ and extracted with chloroform $(5 \times 500$ $\mathrm{mL})$. Between the water and chloroform phases an emulsified phase was formed. The emulsified phase was evaporated to dryness to give the fraction containing the saponins (19 g). Part of this residue was repeatedly chromatographed to give compounds 1 (17 mg), 2 (13 mg) and pure compounds $\mathbf{3}(26 \mathrm{mg})$ and $\mathbf{4}(17 \mathrm{mg})$.

\section{Acid hydrolysis}

Compounds 2, 3 and $\mathbf{4}$ were hydrolyzed on TLC plates in order to identify their sugars, as described by Kartnig and Wegschaider (1972).

\section{Acetylation of compounds 1, 2 and 4}

Compounds 1 (3 mg), 2 (3 mg) and 4 (6 mg) were acetylated with acetic anhydride/pyridine $(1: 1)$ at room temperature overnight, affording peracetylated compounds 1a, $\mathbf{2 a}$ and $\mathbf{4 a}$.

Acetylated derivative (1a):

Acetylated brevicuspic acid $[20(\mathrm{~S})-3 \beta, 19 \alpha$-dihydroxyurs12-en-23,28-dioic acid] (1)

White powder, $\mathrm{mp} 232-235^{\circ} \mathrm{C} .[\alpha]^{20}{ }_{589}+33^{\circ},[\alpha]^{20}{ }_{578}$ $+80^{\circ},[\alpha]^{20}{ }_{546}+94^{\circ}$ and $[\alpha]^{20}{ }_{436}+182^{\circ}(\mathrm{MeOH}, c 0.17)$. IR $v^{\mathrm{KBr}} \mathrm{cm}_{\max }^{-1}: 3425,2932,1741,1698,1456,1372,1237$, 1030. FAB-MS (positive-ion mode, mNBA) $\mathrm{m} / \mathrm{z}: 567.3$ $[\mathrm{M}+\mathrm{Na}]^{+}, 467.2,421.3,338.3$. EIMS $m / z: 544.4[\mathrm{M}]^{+}$, 426.4, 498.4, 482.4, 438.3, 426.4, 407.3. HRMS: $\left.526.3291\left[\mathrm{M}-\mathrm{H}_{2} \mathrm{O}\right]\right]^{+} .{ }^{1} \mathrm{H}$ NMR (Table I) and ${ }^{13} \mathrm{C}$ NMR (Table II).

Brevicuspisaponin 3(2):

[3-O- $\alpha$-L-arabinopyranosyl-20(S)-pomolic acid-28-O- $\beta$ D-glucopyranosyl ester]

FAB-MS (positive-ion mode, mNBA) $\mathrm{m} / \mathrm{z}: 789.4$ $[\mathrm{M}+\mathrm{Na}]^{+}, 703.4,687.4,613.1,599.1,531.2$.

Peracetylated derivative (2a):

White powder, $\mathrm{mp} 153-155^{\circ} \mathrm{C} \cdot[\alpha]^{20}{ }_{589}+17^{\circ}$, $[\alpha]^{20}{ }_{578}+21^{\circ},[\alpha]^{20}{ }_{546}+23^{\circ},[\alpha]^{20}{ }_{436}+39^{\circ}$ and $[\alpha]^{20}{ }_{365}+61^{\circ}$ $\left(\mathrm{CHCl}_{3}, c 0.21\right)$. IR ${ }^{\mathrm{KBr}}{ }_{\max } \mathrm{cm}^{-1}: 3481,2946,1752,1370$, 1224, 1056. FAB-MS (positive-ion mode, $\mathrm{mNBA}$ ) $\mathrm{m} / \mathrm{z}$ : $1083.4[\mathrm{M}+\mathrm{Na}]^{+}, 904.4,850.4,783.3,683.4,667.2$, 613.3. ${ }^{1} \mathrm{H}$ NMR (Table I) and ${ }^{13} \mathrm{C}$ NMR (Table II).

\section{ILA-1(3):}

[3 $\beta$-O- $\alpha$-L-arabinopyranosyl-20(S) - $19 \alpha, 24$ dihydroxyursolic acid-28-O- $\beta$-D-glucopyranosyl ester]

White powder, mp $200-204^{\circ} \mathrm{C}[\alpha]^{20}{ }_{589}+12^{\circ},[\alpha]^{20}{ }_{578}$ $+13^{\circ},[\alpha]^{20}{ }_{546}+14^{\circ},[\alpha]^{20}{ }_{436}+24^{\circ}$ and $[\alpha]^{20}{ }_{365}+37^{\circ}(\mathrm{MeOH}$, $c 0.25) . \mathrm{IR} \mathrm{n}^{\mathrm{KBr}} \mathrm{cm}^{-1}: 3437,2932,1734,1637,1382$, 1074. FAB-MS (positive mode, mNBA) $\mathrm{m} / \mathrm{z}: 805.3$ $[\mathrm{M}+\mathrm{Na}]^{+}, 642,482,411 .{ }^{1} \mathrm{H}$ NMR (Table I) and ${ }^{13} \mathrm{C}$ NMR (Table II). 
Brevicuspisaponin 4 (4):

[23-sodium salt of (20S)-3 $\beta, 19 \alpha, 24$-trihydroxyurs-12-en23,28-dioic acid-28 $\beta$-O- $\beta$-D-glucopyranosyl ester]

FABMS (positive-ion mode, thioglycerol) $\mathrm{m} / \mathrm{z}$ : $725.3[\mathrm{M}+\mathrm{Na}]^{+}, 703.3[\mathrm{M}+\mathrm{H}]^{+}, 539.2\left[\mathrm{M}-\mathrm{C}_{6} \mathrm{H}_{11} \mathrm{O}_{5}\right] . \mathrm{IR}$ $v^{\mathrm{KBr}} \mathrm{cm}_{\max }^{-1}: 3422,2930,1735,1573,1457,1383,1232$, 1073.

Peracetylated derivative (4a):

White powder, $\mathrm{mp} 153-155^{\circ} \mathrm{C}$. FAB-MS (positiveion mode, mNBA) $m / z$ : $955.4[\mathrm{M}+\mathrm{H}]^{+1} \mathrm{H}$ NMR (Table I) and ${ }^{13} \mathrm{C}$ NMR (Table II).

\section{RESULTS AND DISCUSSION}

Triterpene $\mathbf{1}$ and saponins $\mathbf{2}, \mathbf{3}$ and $\mathbf{4}$ were isolated from the emulsified phase obtained from the leaves of the title plant, using the procedure described in the experimental section. Due to difficulty in purifications, compounds 1, 2 and 4 were acetylated in order to afford pure compounds 1a, $\mathbf{2 a}$ and $\mathbf{4 a}$.

EIMS spectrum of $\mathbf{1 a}$ display a molecular peak at $\mathrm{m} /$ $z 544\left[\mathrm{M}^{+}\right]$as molecular ion, which together with the HRMS from the fragment ion with $m / z 526.3291\left[\mathrm{M}^{+}-\right.$ $\mathrm{H}_{2} \mathrm{O}$ ] suggested the molecular formula $\mathrm{C}_{32} \mathrm{H}_{48} \mathrm{O}_{7}$. The triterpenoid structure was confirmed by the ${ }^{1} \mathrm{H}$ broadbanddecoupled ${ }^{13} \mathrm{C}$ NMR experiment which exhibited the presence of one acetyl group $\left(\delta_{C} 170.2\right.$ and 21.1) and thirty other carbon atoms. The DEPT subspectra revealed the presence of six methyl, nine methylene, six methane groups. It was possible to recognize the existence of two carboxy groups $\left(\delta_{\mathrm{C}} 180.7\right.$ and 179.2$)$, one double bond $\left(\delta_{\mathrm{C}}\right.$ 126.8 and 139.5), one acetylated sec alcohol group $\left(\delta_{C}\right.$ $78.5)$ and one tert alcohol group $\left(\delta_{C} 73.3\right)$. The ${ }^{1} \mathrm{H}$ NMR spectrum showed the presence of five angular methyl groups $\left(\delta_{\mathrm{H}} 0.94,1.05,1.42,1.52\right.$ and 1.68) and one methyl group attached to $\mathrm{CH}\left(\delta_{\mathrm{H}} 1.10, d,{ }^{3} \mathrm{~J}=7.0 \mathrm{~Hz}\right)$, suggesting an ursane or oleanane derivative. The multiplicities at $\delta_{\mathrm{H}}$ $5.76\left(3 \alpha-\mathrm{H}, d d,{ }^{3} J=12.0\right.$ and $\left.3.4 \mathrm{~Hz}\right)$ indicated a $3 \beta-$ hydroxy substitution on this skeleton. HMBC experiment allowed to locate $24-\mathrm{CH}_{3}\left(\delta_{\mathrm{C}} 12.8\right)$ and $23-\mathrm{COOH}\left(\delta_{\mathrm{C}}\right.$ $179.2)$ at $\mathrm{C}-4$. NOE enhancements were detected for $25 \beta$ $\mathrm{CH}_{3}\left(\delta_{\mathrm{H}} 0.94, \mathrm{~s}\right)$ and $24-\mathrm{CH}_{3}\left(\delta_{\mathrm{H}} 1.52, \mathrm{~s}\right)$ in a ROESY experiment, indicating the 4a-configuration of the carboxy group.

In the ${ }^{1} \mathrm{H}$ NMR spectrum, the deshielded methylene hydrogen proton at $\delta_{\mathrm{H}} 3.19$ showed characteristic multiplicities ( $t d, J=12.9$ and $3.8 \mathrm{~Hz}$ ) that established an axial relative stereochemistry for $16 \alpha-\mathrm{H}$. It was confirmed through the $W$-type correlation observed between proton signals at $\delta_{\mathrm{H}} 2.02$ (equatorial $16 \beta-\mathrm{H}$ ) and $\delta_{\mathrm{H}} 3.26$ (equato-
TABLE I - ${ }^{13} \mathrm{C}-\mathrm{NMR}$ data for the acetylated derivatives 1a, 2a and $4 \mathbf{a}$, and compound $\mathbf{3}$ (pyridine- $\mathrm{d}_{5}$ )

\begin{tabular}{|c|c|c|c|c|}
\hline $\mathrm{C}$ & $1 a^{*}$ & $2 \mathrm{a}^{*}$ & 3 & $4 a$ \\
\hline 1 & 38.2 & 38.7 & 38.7 & 38.8 \\
\hline 2 & 23.5 & 26.7 & 27.0 & 24.0 \\
\hline 3 & 78.5 & 89.5 & 89.2 & 77.9 \\
\hline 4 & 52.1 & 39.4 & 44.4 & 54.9 \\
\hline 5 & 52.0 & 55.9 & 56.4 & 52.6 \\
\hline 6 & 21.3 & 18.7 & 19.1 & 23.1 \\
\hline 7 & 33.2 & 33.8 & 33.8 & 34.2 \\
\hline 8 & 40.5 & 40.4 & 40.5 & 40.6 \\
\hline 9 & 47.8 & 47.8 & 47.8 & 48.1 \\
\hline 10 & 36.7 & 37.2 & 36.9 & 37.0 \\
\hline 11 & 23.9 & 24.1 & 24.8 & 24.2 \\
\hline 12 & 126.8 & 128.1 & 127.7 & 127.7 \\
\hline 13 & 139.5 & 138.4 & 139.0 & 138.4 \\
\hline 14 & 42.1 & 42.3 & 42.3 & 42.1 \\
\hline 15 & 29.2 & 29.3 & 29.3 & 29.2 \\
\hline 16 & 27.0 & 26.8 & 26.9 & 26.6 \\
\hline 17 & 47.9 & 48.6 & 48.5 & 48.6 \\
\hline 18 & 47.4 & 47.2 & 47.3 & 47.1 \\
\hline 19 & 73.3 & 73.4 & 73.5 & 73.3 \\
\hline 20 & 43.2 & 42.9 & 43.0 & 42.9 \\
\hline 21 & 24.9 & 24.7 & 24.4 & 24.7 \\
\hline 22 & 32.4 & 31.8 & 32.0 & 31.7 \\
\hline 23 & 179.2 & 28.1 & 23.6 & 176.5 \\
\hline 24 & 12.8 & 17.0 & 63.5 & 63.9 \\
\hline 25 & 15.8 & 15.7 & 15.6 & 15.5 \\
\hline 26 & 17.1 & 17.5 & 17.5 & 17.1 \\
\hline 27 & 24.3 & 24.3 & 24.7 & 24.1 \\
\hline 28 & 180.7 & 176.5 & 177.2 & 176.4 \\
\hline 29 & 29.8 & 29.8 & 30.0 & 29.6 \\
\hline 30 & 16.1 & 16.1 & 16.2 & 16.0 \\
\hline Ara-1' & & 104.0 & 106.7 & \\
\hline Ara-2' & & 70.5 & 73.0 & \\
\hline Ara-3, & & 71.5 & 74.7 & \\
\hline Ara-4' & & 69.1 & 69.6 & \\
\hline Ara-5, & & 64.1 & 66.9 & \\
\hline$\overline{\text { Glc-1" }}$ & & 92.5 & 96.0 & 92.4 \\
\hline Glc-2" & & 71.1 & 74.3 & 71.0 \\
\hline Glc-3" & & 73.6 & 79.1 & 73.6 \\
\hline Glc-4" & & 69.0 & 71.2 & 69.0 \\
\hline Glc-5" & & 73.2 & 79.5 & 73.1 \\
\hline Glc-6" & & 62.3 & 62.3 & 62.3 \\
\hline
\end{tabular}

*Values for the acetyl groups are not recorded in the table. Acetyl groups: $\delta_{\mathrm{C}} \cong 20\left(\mathrm{CH}_{3}\right)$ and $\delta_{\mathrm{C}} \cong 168(\mathrm{C}=\mathrm{O})$. 
TABLE II - ${ }^{1} \mathrm{H}-\mathrm{NMR}$ data for the acetylated derivatives 1a, $\mathbf{2 a}$ and $\mathbf{4 a}$, and compound $\mathbf{3}$ (pyridine- $\mathrm{d}_{5}$ ) (multiplicities; $J=\mathrm{Hz}$ )

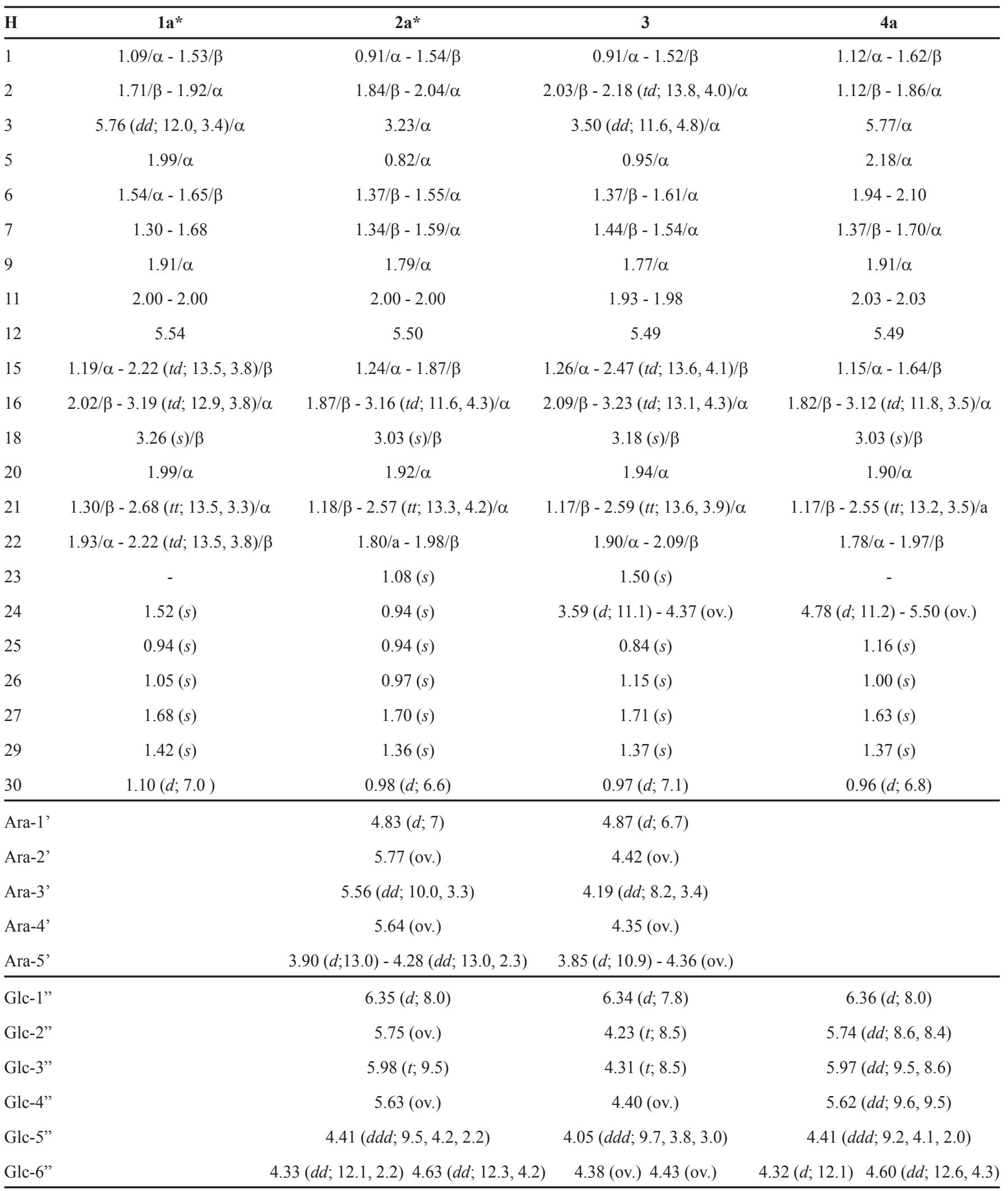

*Values for the acetyl groups are not recorded in the table. 
rial $18 \beta-\mathrm{H})$ in the HH COSY experiment. Further, evidence for an equatorial $18 \beta-\mathrm{H}$ was provided by heteronuclear long-range correlation via three bonds couplings, ${ }^{3} J\left({ }^{13} \mathrm{C},{ }^{1} \mathrm{H}\right)$, detected by the HMBC experiment. This proton displayed cross-signals with carbons $\mathrm{C}-14\left(\delta_{\mathrm{C}} 42.1\right)$ and $\mathrm{C}-16\left(\delta_{\mathrm{C}} 27.0\right)$, revealing a dihedral angle close to $180^{\circ}$, providing evidence for the cis-fusion between the rings D/E.

A triplet of triplets ( ${ }^{3} \mathrm{~J}=13.3$ and $3.3 \mathrm{~Hz}$ ) observed for $21 \alpha-\mathrm{H}\left(\delta_{\mathrm{H}} 2.68\right.$, axial $)$ revealed the $\beta$-configuration of the C-30 methyl group $\left(\delta_{\mathrm{H}} 16.1\right)$, corresponding to an ursane derivative with the $20(S)$-configuration that could be confirmed by means of the ROESY experiment, indicating spatial correlation between the $18 \beta-\mathrm{H}\left(\delta_{\mathrm{H}} 3.26\right)$ and hydrogens $29 \beta-\mathrm{CH}_{3}\left(\delta_{\mathrm{H}} 1.42\right)$ and $30 \beta-\mathrm{CH}_{3}\left(\delta_{\mathrm{H}} 1.10\right)$. Compared with ursolic acid (Tkachev et al., 1994), compound 1a presented two important $\gamma$-effects in the ring E. The first one was caused by the axial $30 \beta-\mathrm{CH}_{3}$, shielding the carbons $\mathrm{C}-18$ and $\mathrm{C}-22$ by 5 and $4 \mathrm{ppm}$, respectively, in the ${ }^{13} \mathrm{C}$ NMR. The second effect was observed due to the presence of the axial $19 \alpha$-hydroxy group, that shielded C-21 by about 6 ppm. Thus, 1a differs from the structure of rotundioic acid (Nakatni et al., 1989) by a different configuration of C-20 and turns out to be the peracetylated derivative of $20(S)-3 \beta, 19 \alpha$-dihydroxyurs12-en-23,28-dioic acid, named brevicuspic acid.

Fast atom bombardment mass spectroscopy (FABMS, positive mode) of $\mathbf{2 a}$ generated a fragment at $\mathrm{m} / \mathrm{z}$ $1083[\mathrm{M}+\mathrm{Na}]^{+}$as a pseudo molecular ion, in accordance with seven acetylated $\mathrm{OH}$ groups and with the spectrum obtained for the non-peracetylated compound $\mathbf{2}$, showing a pseudo molecular ion at $m / z=789[\mathrm{M}+\mathrm{Na}]]^{+} \cdot{ }^{13} \mathrm{C}$ NMR of $2 \mathbf{a}$ data revealed the occurrence of signals from one carboxy carbon $\left(\delta_{\mathrm{C}} 176.5\right)$, seven acetate groups $\left(\delta_{\mathrm{C}} 169\right.$ - 170 and $\left.\delta_{C} 20.7-21.1\right)$, one double bond $\left(\delta_{C} 128.1\right.$ and a)

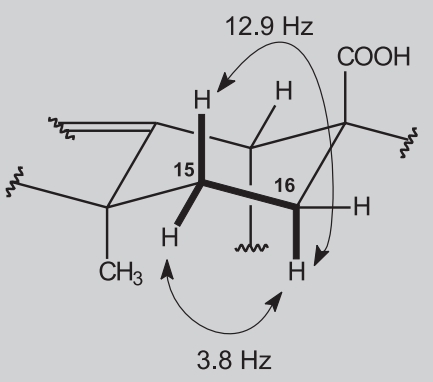

b)

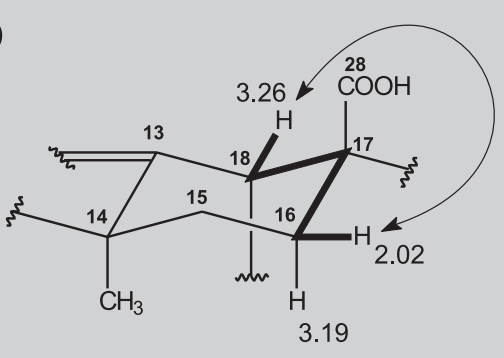

c)

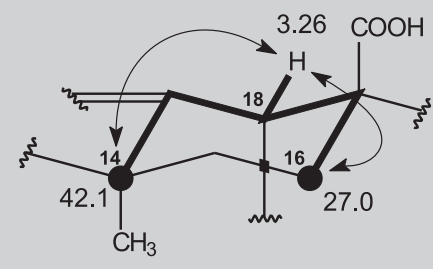

FIGURE 1 - Ring D from 1a: additional evidence for the relative configuration by the ${ }^{1} \mathrm{H}$ NMR coupling constants (a), $W$-type correlation deduced from the HH COSY diagram $(\mathbf{b})$ and long-range correlation ${ }^{3} J\left({ }^{13} \mathrm{C},{ }^{1} \mathrm{H}\right)$ in the HMBC experiments (c).
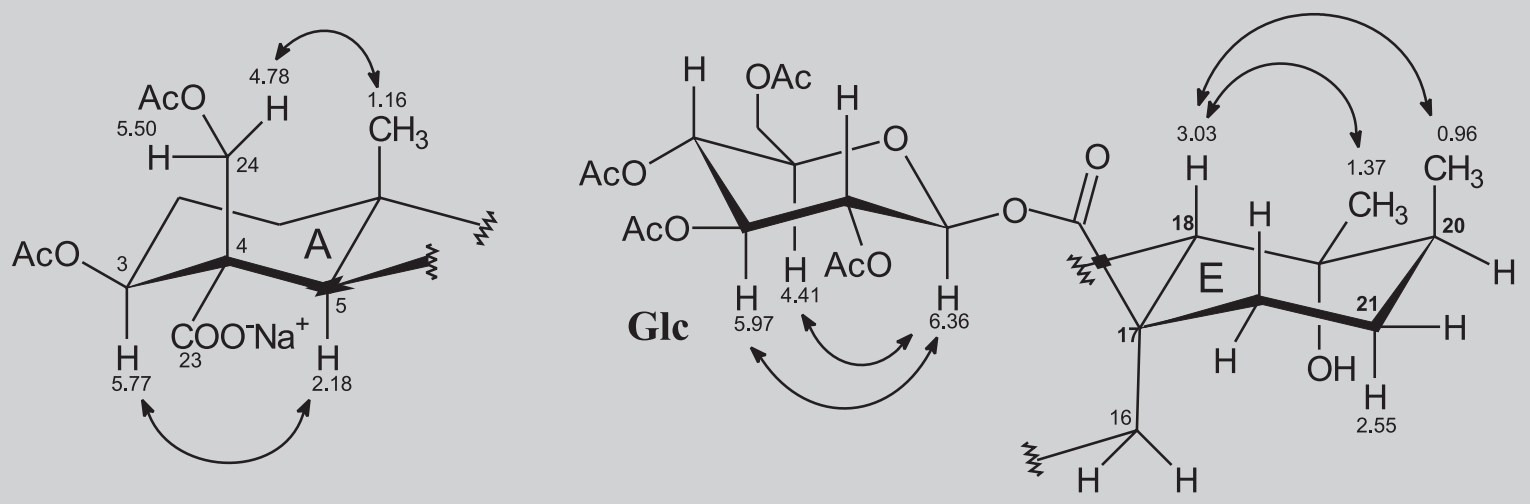

FIGURE 2 - Main ROESY correlation observed for compound 4 a in pyridine- $d_{5}$. 
138.4), two anomeric carbons $\left(\delta_{C} 104.0\right.$ and 92.5$)$, one glycosylated sec alcohol $\left(\delta_{C} 89.5\right)$ and one tert alcohol $\left(\delta_{C}\right.$ 73.4). ${ }^{1} \mathrm{H}$ NMR confirmed the presence of six angular methyl groups $\left(\delta_{\mathrm{H}} 2 \mathrm{x} 0.94,0.97,1.08,1.36\right.$ and 1.70$)$, one methyl group attached to $\mathrm{CH}\left(\delta_{\mathrm{H}} 0.98, d,{ }^{3} \mathrm{~J}=6.6 \mathrm{~Hz}\right)$, one olefinic proton $\left(\delta_{\mathrm{H}} 5.50\right)$ and two anomeric sugar protons $\left(\delta_{\mathrm{H}} 4.83, d,{ }^{3} J=8.0 \mathrm{~Hz}\right.$ and $\left.\delta_{\mathrm{H}} 6.35, d,{ }^{3} J=8.0 \mathrm{~Hz}\right)$. Both sugars presented antiperiplanar configuration of 1'-H and $2^{\prime}-\mathrm{H}\left({ }^{3} J=8.0 \mathrm{~Hz}\right)$, reflecting the $\alpha$-configuration of the Larabinopyranose and the $\beta$-configuration of the $\mathrm{D}$ glucopyranose. The glycosidic linkages were established using the HMBC techniques. It was possible to observe correlation between the anomeric proton of $\alpha$-L-arabinose $\left(\delta_{\mathrm{H}} 4.83\right)$ and $\mathrm{C}-3\left(\delta_{\mathrm{C}} 89.5\right)$, and also between the anomeric proton of $\beta$-D-glucose $\left(\delta_{\mathrm{H}} 6.35\right)$ and $\mathrm{C}-28\left(\delta_{\mathrm{C}} 176.5\right)$.

ROESY experiments were used to establish the $\alpha$ configuration for 1' $-\mathrm{H}\left(\delta_{\mathrm{H}} 4.83\right), 3-\mathrm{H}\left(\delta_{\mathrm{H}} 3.23\right)$ and $23-\mathrm{CH}_{3}$ $\left(\delta_{\mathrm{H}} 1.08, s\right)$. Moreover, the $\beta$-configuration of $29-\mathrm{CH}_{3}\left(\delta_{\mathrm{H}}\right.$ $1.36, s)$ attached to $\mathrm{C}-19\left(\mathrm{~d}_{\mathrm{C}} 73.4\right)$ indicated the presence of a $19 \alpha$-tert alcohol group. In the same way, the $\alpha$ configuration of $20-\mathrm{H}\left(\delta_{\mathrm{H}} 1.92\right)$ defined the configuration $30 \beta-\mathrm{CH}_{3}\left(\delta_{\mathrm{H}} 0.98, d,{ }^{3} \mathrm{~J}=6.6 \mathrm{~Hz}\right)$ at $\mathrm{C}-20$. These data indicated the aglycone to be the 20(S)-isomer of pomolic acid (Brieskorn et al., 1967) and compound 2a was elucidated as the peracetylated derivative obtained from the 3-O- $\alpha$-L-arabinopyranosyl-20(S)-pomolic acid-28-O$\beta$-D-glucopyranosyl ester, named brevicuspisaponin 3.

Examination of compound $\mathbf{3}$ allowed its characterization as ILA-1, a saponin already isolated from the leaves of Ilex argentina (Schenkel et al.,1995). One- and twodimensional NMR spectroscopic data confirmed 3 as 3-O$\alpha$-L-arabinopyranosyl-20(S)-19 $\alpha, 24$-dihydroxyursolic acid-28-O- $\beta$-D-glucopyranosyl ester.

Compound $\mathbf{4}$ was characterized as a sodium salt by IR that shows a symmetric stretching band at $1573 \mathrm{~cm}^{-1}$, a diagnostic frequency for a carboxylic acid salt. The presence of the sodium was determined by the flame ionization, employing a polarized filter for the D-sodium line, and compounds $\mathbf{3}$ as negative control. Acidic hydrolysis on TLC plates (Kartning, Wegschaider, 1972) indicated the presence of glucose. The FABMS of this genuine saponin (positive-ion mode) displayed peaks at $m / z=725.3[\mathrm{M}+\mathrm{Na}]^{+}$and $703.3[\mathrm{M}+\mathrm{H}]^{+}$. Compound 4a showed the pseudo-molecular ion by FABMS (positiveion mode) at $m / z=955.4[\mathrm{M}+\mathrm{H}]^{+}$.

${ }^{13} \mathrm{C}$ NMR spectra of compound $\mathbf{4 a}$ revealed the presence of signals of two carboxy carbons $\left(\delta_{\mathrm{C}} 176.4\right.$ and 176.5), one double bond $\left(\delta_{C} 127.7\right.$ and 138.4), one anomeric sugar carbon $\left(\delta_{\mathrm{C}} 92.4\right)$, one sec-hydroxyl $\left(\delta_{\mathrm{C}}\right.$ $77.9)$, one tert-hydroxyl functions $\left(\delta_{\mathrm{C}} 73.3\right)$ and two hydroxymethyl groups $\left(\delta_{\mathrm{C}} 62.3\right.$ and 63.9$)$. The ${ }^{1} \mathrm{H}$ NMR spectrum showed the presence of four angular methyl groups $\left(\delta_{\mathrm{H}} 1.00,1.16,1.37\right.$ and 1.63), one methyl group attached to $\mathrm{CH}\left(\delta_{\mathrm{H}} 0.96, d,{ }^{3} J_{H H}=6.8 \mathrm{~Hz}\right)$, one olefinic proton $\left(\delta_{\mathrm{H}} 5.49\right)$ and one anomeric sugar proton $\left(\delta_{\mathrm{H}} 6.36\right.$, $\left.d,{ }^{3} J_{H H}=8.0 \mathrm{~Hz}\right)$. Its NMR data comparison with compound 2a (table 2) indicated that the sugar $\beta$-Dglucose was esterified with the $\mathrm{C}-28$ carboxy function in the aglycone.

The location of the carboxylate group at C-4 was derived from the HMBC correlation signals $\delta_{\mathrm{C}} 176.5 \leftrightarrow \delta_{\mathrm{H}}$ $4.78\left(24_{A}-\mathrm{H}\right)$ and $5.50\left(24_{B}-\mathrm{H}\right)$. Moreover, the carbon resonance of this hydroxymethyl group presented long-range correlation with the signals at $\delta_{\mathrm{H}} 5.77(3 \alpha-\mathrm{H})$ and 2.18 $(5 \alpha-\mathrm{H})$. The occurrence of a triplet of triplets at $\delta_{\mathrm{H}} 2.55$ $\left(J_{H H}=13.2\right.$ and $\left.3.5 \mathrm{~Hz}\right)$ indicated an axial hydrogen $21 \alpha-\mathrm{H}$ and thus, the $(20 S)$-configuration. It was corroborated through spatial correlation observed between $18 \beta-\mathrm{H}\left(\delta_{\mathrm{H}}\right.$ $3.03)$ and hydrogens $29 \beta-\mathrm{CH}_{3}\left(\delta_{\mathrm{H}} 1.37\right)$ and $30 \beta-\mathrm{CH}_{3}\left(\delta_{\mathrm{H}}\right.$ $0.96 ; d,{ }^{3} J_{H H}=6.8 \mathrm{~Hz}$ ) in the ROESY diagram (Figure 2). Furthermore, ROESY correlation between signals at $\delta_{\mathrm{H}}$ $4.78\left(24_{A} \beta-H\right)$ and $\delta_{H} 1.16\left(25 \beta-\mathrm{CH}_{3}\right)$ also established the configuration on $\mathrm{C}-4$ and located the sodium carboxylate group at $\mathrm{C}-23$ ( $4 \alpha$-configuration). This experiment also showed the correlation between $3 \alpha-\mathrm{H}\left(\delta_{\mathrm{H}}\right.$ 5.77) and $5 \alpha-\mathrm{H}$ $\left(\delta_{\mathrm{H}} 2.18\right)$. Thus, compound $\mathbf{4 a}$ is a new saponin and was elucidated as the peracetylated derivative from of the 23-

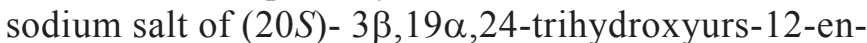
23,28 -dioic acid-28 $\beta-O-\beta$-D-glucopyranosyl ester, named brevicuspisaponin 4 .

Considering these and the previous published results (Taketa et al., 2000), the saponin profile of I. Brevicuspis leaves is markedly different from those found in $I$. paraguariensis leaves. The latter presents saponins derived from the oleanolic and ursolic acid without oxygenated functions at C-19, C-23 or C-24, as demonstrated to $I$. brevicuspis. These are important features that may be useful to develop methodologies for the quality control of maté products based on the characterization of the free triterpenes or the saponins.

\section{ACKNOWLEDGMENTS}

We are grateful to the Botanist Geraldo C. Coelho from the Departamento de Biologia e Química of Universidade de Ijuí, Ijuí/RS for locating, identifying and helping to collect the plant material, to Dr. G. Eckhardt and to Mrs. U. Dahmen (Bonn University), for recording the mass and IR spectra. This work was supported by research stipends from DAAD (Germany), and CNPq (Brazil). 


\section{RESUMO}

\section{Novos triterpenos e glicosídeos triterpenóides de Ilex brevicuspis}

Das folhas de Ilex brevicuspis foram isolados e identifi-

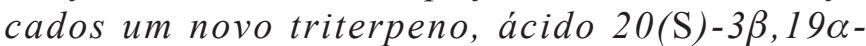
diidroxiurs-12-en-23,28-dióico, denominado ácido brevicúspico, e dois novos glicosídeos, éster 28-O- $\beta-D-$ glicopiranosil do ácido $3 \beta$-O- $\alpha$-L-arabinopiranosil20 (S)-pomólico e o sal sódico em $C$ - 23 do ester $28 \beta$-O- $\beta$ $D$-glicopiranosil do ácido (20S)- 3 $\beta, 19 \alpha, 24$-triidroxiurs12 -en-23,28-dióico. Foi isolado ainda o éster 28-O- $\beta$ - $D$ glicopiranosil do ácido $3 \beta$-O- $\alpha$-L-arabinopiranosil20 (S)-19 $\alpha$,24-diidroxiursólico, já descrito anteriormente para a espécie Ilex argentina. As estruturas foram estabelecidas por métodos espectroscópicos e químicos.

UNITERMOS: Aquifoliaceae. Ilex brevicuspis. Triterpenos. Saponinas. Ácido brevicúspico. Brevicuspisaponinas 3 e 4.

\section{REFERENCES}

ATHAYDE, M. L., SCHENKEL, E. P., GOSMANN, G., GUILLAUME, D. Triterpenoids from the leaves of Ilex theezans Martius ex Reiss. Acta Farm. Bonaerense, v. 18, p. 49-52, 1999.

ATHAYDE, M. L., SCHENKEL, E.P., GNOATO, S., GOSMANN, G., GIBERTI, G.C., GUILLAUME D. Triterpenes and saponins from Ilex argentina leaves. Acta Farm. Bonaerense, v. 20, p.13-16, 2001.

BRIESKORN, C. H., WUNDERER, H. Pomol- und Pomolsäure. Chem. Ber., v. 100, p. 1252-1253, 1967.

HEINZMANN, B.M., SCHENKEL, E. P. Saponins from Ilex dumosa. J. Nat. Prod., v. 58, p. 1419-1422, 1995.

KARTING, T., WEGSCHAIDER, O. Zur Kenntnis der Saponine aus Herniaria glabra. Planta Med., v. 21, p.144-150, 1972.
NAKATANI, M., MIYAZAKI, Y., IWASHITA, T., NAOKI, H., HASE, T. Triterpenes from Ilex rotunda fruits. Phytochemistry, v. 28, p.1479-1482, 1989.

PIRES, V. S., GUIllaUME, D., GOSMANN, G., SCHENKEL, E. P. "Erva-Mate" adulterating plants: saponins from Ilex dumosa. J. Agric. Food Chem., v. 45, p.1027-1031, 1997.

REGINATTO, F. H., ATHAYDE, M. L., GOSMANN, G., SCHENKEL, E. P. Methylxanthines accumulation in Ilex Species - Caffeine and theobromine in erva-mate (Ilex paraguariensis) and other Ilex species. J. Braz. Chem. Soc. v. 10, p.443-446, 1999.

SCHENKEL, E. P., ATHAYDE, M. L., GIBERTI, G. C., GUILLAUME, D. A new saponin from Ilex argentina. Acta Farm. Bonaerense, v.14, p.5-10, 1995.

SCHENKEL, E.P., GOSMANN, G., MONTANHA, J.A., HEINZMANN, B.M., ATHAYDE, M.L., TAKETA, A.T.C., PIRES, V., GUILLAUME, D. Saponins from maté Ilex paraguariensis and other South American Ilex species: Ten years research on Ilex saponins. Ciênc. Cult., v. 49, p.315-320, 1997.

TAKETA, A. T. C., SCHENKEL, E. P. Saponins from Ilex pseudobuxus. Acta Farm. Bonaerense, v.13, p.159-164, 1994.

TAKETA, A. T. C., SCHMITTMANN-SCHLAGER, T., GUILLAUME, D., GOSMANN, G., SCHENKEL, E.P. Triterpenoid glycosides and a triterpene from Ilex brevicuspis. Phytochemistry, v. 53, p. 901-904, 2000.

TKACHEV, A. V., DENISOV, A. Y., GATILOV, Y. V., BAGRYANSKAYA, I. Y., SHEVTSOV, S. A., RYBALOVA, T. V. Stereochemistry of hydrogen peroxide-acetic acid oxidation of ursolic acid and related compounds. Tetrahedron, v. 50, p.11459-11462, 1994.

Recebido para publicação em 20/12/01. 